УДК 7.038.6+141.78](4)"197/200"(045)

ORCID ID: https://orcid.org/0000-0002-1724-6395

\begin{abstract}
Журавльова Тетяна Василівна, кандидат мистецтвознавства, старший викладач кафедри кінознавства. Київський національний університет театру, кіно і телебачення імені І. К. Карпенка-Карого, Київ
\end{abstract}

Tetiana Zhuravliova,

a Ph.D. in Art Criticism, a senior research fellow of cinematology Departament. Kyiv National I. K. Karpenko-Karyi Theatre, Cinema and Television University, Kyiv

\title{
МЕЛОДРАМАТИЧНИЙ МОДУС В УКРАЇНСЬКОМУ ПОЕТИЧНОМУ КІНЕМАТОГРАФІ
}

Анотація. У статті досліджується вплив жанру мелодрами на структуру фільмів українського поетичного кінематографа. Жанровий аспект у фільмах цього напряму досі грунтовно не досліджувався. Методологія модусного дослідження художнього тексту дає змогу виявити наявні в межах твору чи системи творів смислові та сюжетні елементи, які вибудовуються в так звані модусні конструкції. На підставі спільних естетичних чинників можемо досліджувати типологію екранних творів з позиції закономірностей їхньої сюжетно-образної системи.

Опертя на інтертекстуальний принцип аналізу екранного твору в деяких стрічках дає змогу виявити спорідненість смислових і сюжетних елементів. Також акцентовано увагу на наявності мистецького діалогу між зазначеними кінотекстами.

Ключові слова: поетичний кінематограф, мелодрама, жанровий модус, інтертекстуальність.

Постановка проблеми та актуальність дослідження. Фільми українського поетичного кінематографа досі грунтовно не досліджувалися з позиції жанрового впливу на екранний текст. Також у межах цього художнього напряму не робилося спроб типології кінострічок на підставі будь-якого жанру. Спираючись на інтертекстуальний підхід до аналізу екранного твору, в деяких стрічках можемо виявити спорідненість смислових і сюжетних елементів. Таким чином, між кінотекстами виникає мистецький діалог, також вони досліджуються в одному контекстуальному просторі.

Виявити наявні в межах твору чи системи творів подібні ознаки дає можливість методологія модусного аналізу художнього тексту. Під модусом у цьому разі розуміється спосіб існування елементів певного жанру у групі кінематографічних творів.

Мелодрама безперечно мала вплив на художню структуру багатьох стрічок цього напряму. Формулу: архетип-мотив-фабула, виявлену в різноманітних сюжетах про «нещасливе ко- хання» - як структуротворчий принцип мелодраматичної оповіді, можемо вважати іiї жанровим модусом.

Дослідження смислового поля українського поетичного кінематографа, виявляє історичні традиції вітчизняної художньої культури. Її феномен полягає в апелюванні до особливостей національного менталітету. Адже українська культура (від традиційного, народного до академічного мистецтва) завжди характеризувалась високоемоційним сприйняттям дійсності. Константні ознаки жанру мелодрами (апеляція до емоційно-етичної сфери, наявність героя, який невинно страждає, ідеалізація уявлень про справедливість буття тощо) суголосні рисам національного менталітету, архетипам, що $є$ його основою.

Етнічний фактор актуалізує як самобутність української культури, її спроможність зберігати свої духовні та мистецькі засади у глобалізованому світі, так і можливість генерувати нові культурні смисли, актуальні запитам світової художньої культури ідеї. 
Мета дослідження - виявити жанрові принципи побудови екранного тексту в фільмах українського поетичного кінематографа. Визначити естетичні принципи мелодрами у таких фільмах: «Тіні забутих предків» С. Параджанова, «Білий птах 3 чорною ознакою» Ю. Іллєнка та «Вавилон ХХ» I. Миколайчука. Довести, що і авторський кінематограф, і твори популярної екранної культури живляться подібними жанровими стереотипами, що лише доводить необхідність детальнішого дослідження вітчизняним кінознавством популярних екранних жанрів.

Аналіз сучасних досліджень $і$ публікацій: дослідження спирається на одні з останніх публікацій провідних кінознавців, які продовжують аналізувати фільми поетичного кінематографа, застосовуючи новітні філософські, мистецтвознавчі та культурологічні підходи. Зокрема це праці Л. Брюховецької «”Тіні забутих предків” як художній маніфест» (2014), В. Скуратівського «Тіні забутих фільмів» (2014), О. Мусієнко «Українське кіно: тексти і контекст» (2009) та ін.

Виклад основного матеріалу: Авторка дослідження ставить перед собою завдання - звести фільми української поетичної хвилі до якогось певного жанрового знаменника. Адже режисери цього напряму якраз уникали жанрового впливу на зміст своїх фільмів. Радше це було несвідомим актом, прагненням відсторонитися від стереотипних уявлень про жанровий кінематограф, а також і про українську культуру. Пізніше теоретики кіно чітко зартикулюють той факт, що будь-які жанрові формули є маркетинговим інструментом. «Маркетинговий» у традиції досвіду ринкових стратегій не є синонімом «низьковартісний» стосовно твору екранної культури. Але час та обставини, у яких творили українські митці згаданого напряму, диктував свої умови існування в ідеологічний парадигмі радянської культури.

Якщо розглядати жанр як певний спосіб інтерпретації та розуміння дійсності, то можна звести жанрове бачення художньої реальності до набору певних стереотипів у сюжетах, образах, мотивах, конфліктах тощо. Новий кінотекст таким чином складається з уже відомих та добре впізнаваних схем та образів.

Методологія модусного дослідження художнього тексту дає змогу виявити наявні в межах твору чи системи творів смислові та сюжетні елементи, які вибудовуються в так звані модусні конструкції. На підставі спільних естетичних чинників можемо досліджувати типологію екранних творів з позиції закономірностей їхньої сюжетнообразної системи.
Основні елементи мелодраматичної «історії» мають міфолого-архетипічну основу. Дослідники масової культури, кінематографа зокрема, ввели в обіг поняття «жанрової формули», на основі якої формується кінооповідь. Це стійка стандартна схема, але наповнена змістом, характерним для певної культурної епохи.

Поняття культурний стереотип понині вважається ознакою переважно масового, популярного мистецтва. Хоча дехто з науковців наголошує, що у масовій та високій культурі існує єдина стратегія використання архетипів: «якщо у творі високої мистецької вартості «зміст» архетипів поглиблюється та індивідуалізується, то у масовому мистецтві він перетворюється на кліше» (Кармилова, 2008, с. 125).

Формулу: архетип-мотив-фабула, як структуротворчий принцип мелодраматичної оповіді можемо вважати іiі жанровим модусом. Цей модус безперечно анявний і в деяких стрічках українського поетичного кінематографа, але великого значення набуває такий елемент наративу, як метафора. Остання не $\epsilon$ ознакою лише цього напряму, не лише елементом художньої виразності суто поетичної форми висловлювання в кіномистецтві. Метафора може перегукуватись із поняттям стереотип, тому вона не $\epsilon$ чужорідним елементом також і для жанрового кіно. Метафора у згаданих стрічках є маркером належності до української екранної культури, коріння якої сягає ще Довженкової «Землі». Візуальні образи, як і сюжетні архетипи та мотиви, так само, як в О. Довженка, - це також маркери української культури, основним чинником якої є її етнічна складова.

У той період, коли було створено програмний фільм поетичної школи «Тіні забутих предків» етнічний чинник в українському радянському кінематографі вже був достатньо звульгаризований, доведений до примітивізму у відтворенні психологічного типу українця.

С. Параджанов надав режисерам певний канон оповіді, етнічний чинник у якому став чи не головним. Проте дослідники українського кіно зауважували, що національна своєрідність «Тіней...», не самоціль, а органічна необхідність, складова його естетичної та етичної сутності: «...лише за умов повної достовірності можна було розкрити характерні ознаки народного світовідчуття, народної моралі» (Брюховецька, 2014, с. 31). В. Скуратівський у статті, присвяченій творчості режисера (2014, c. 40), зауважив, що саме літературне першоджерело (повість М. Коцюбинського) було виявом «драматичної зустрічі «особистісного» і «народного», індивідуальної рефлексії та міфології (2014, с. 41). 
Дослідник вбачає космогонізм у самій фабулі повісті-міфологічній зустрічі «світла» й «тіні».

Л. Аннінський визначив сутність «Тіней...» як трагедію персональної долі, а приреченість Івана, на його думку, полягає у тому, що герой зробив персональний вибір - покохав «не ту». Його власна мораль «протистоїть доособистісній патріархальності, бо мораль $\epsilon<\ldots>$ розв'язанням проблем особистості, моральної свідомості» (Аннінський, 2014 , c. 60$)$.

Людина, яка втілює себе за внутрішнім, усвідомленим, моральним вибором - це герой мелодраматичної світоглядної системи. Притаманні цьому жанру ознаки (не в останню чергу через його гуманістичні ідеали) дослідники пов'язували зі смаками й уподобаннями саме масового реципієнта, оскільки мелодрама спирається на той пласт людських емоцій, який близький до повсякденного досвіду багатьох людей, він концентрує в собі закріплений у сталих образах та колізіях моральний та естетичний досвід багатьох поколінь. Науковці, які намагалися «реабілітувати» мелодраму, наголошували, що мелодраматичне начало змінює свій статус, виходячи за межі власне мелодрами, воно стає характерною рисою мистецтва загалом. 3 вузького мистецтвознавчого поняття мелодраматизм дедалі більше перетворюється на поняття загальнохудожнє (Крутоус, 1981, с. 131).

Наявність ознак мелодрами (мелодраматичного модусу) в тексті фільму С. Параджанова можна вважати не збігом фабульних елементів, а доказом того, що мелодрама спроможна існувати не лише за канонами масового мистецтва.

Імовірно, якби історія кохання Івана та Марічки була обмежена лише моральною проблематикою, у бік «Тіней...» не було б нарікань і звинувачень у формалізмі. Але людські долі у ній були вплетені в «космогонію» буття й потойбіччя, Людини та Всесвіту, конкретного й символічного. Саме тому ідея картини має право на численні потрактування, як, приміром, висловилася Л. Брюховецька: «Людина чуйна, вразлива, поетична, він (Іван - Ж. Т.) зіткнувся з навколишньою дійсністю i, не вміючи та не бажаючи пристосовуватися до неї, трагічно гине» $(2014$, с. 28$)$.

Тематично та ідейно жанр мелодрами у кіноглядача асоціюється саме з розповіддю про любовні взаємини (насправді діапазон мотивів у мелодрамі не обмежується любовними перипетіями). У центрі сюжету - любов, і це почуття спрямоване не лише на об'єкт сексуальної зацікавленості. Материнська любов чи її відсутність (доля сироти, приміром), ностальгія за Батьківщиною - це ціл- ком мелодраматичні мотиви. Щодо останньої, то етична та естетична концепція поетичного кінематографа здебільшого грунтувалась на архетипі «втраченого раю»- на тузі за «альтернативною Україною», країною внутрішньої еміграції багатьох тогочасних митців.

У «Тінях забутих предків» туга за Україноюзабороненою, «надмір етнографічною»- звісно наявна, як і у літературному першоджерелі. Та на поверхні усе ж любовна історія карпатських Ромео та Джульєтти. Страждання Івана по смерті Марічки - це страждання заради кохання, пам'яті про кохання. У мелодрамі саме страждання визначають принцип побудови оповіді та механізм іiї сприйняття. І. Дзюба у епізоді поховання Марічки, де Іван прилаштовує хрест на свіжу могилу коханої і раптом туди дістається молода лань побачив «символ невловимого щастя, недосяжної мрії» (2014, с. 22).

Світ Івана було зруйновано зі смертю Марічки, і такий порядок речей доволі типовий для мелодрами - але лише у експозиції чи зав'язці. Зрештою усе в мелодраматичному сюжеті має стабілізувати втрачену рівновагу. Адже цей жанр експонує впорядковану та ушляхетнену світобудову, де зло має бути покаране, добро піднесене, поневіряння винагороджені тощо. Навіть фінальна смерть героя чи героїні не має залишати у глядача відчуття безвиході - той, хто втратив кохану людину, набуде «очищення стражданням».

Мелодрама має свої, лише їй притаманні рецептивні особливості, герої повинні поводитись відповідно до життєвої, житейської логіки, нехай би вона завдавала їм іще більших страждань, але у глядача має справлятися враження, що «в житті» таке часто трапляється.

Мелодраматичний модус експонує героя в найуразливішому стані, коли він слабкий і розгублений перед викликами життя. Лише тоді може виникнути емпатія - співпереживання персонажу. Дослідники мелодрами у літературі, театрі, кінематографі припускають, що мелодраматичний модус, який і спричиняє процес співчуття «сягає архаїчного ритуалу з цапом-відбувайлом, як відомо мета цього ритуалу полягала в очищенні його учасників від скверни, сюжет мелодрами найчастіше варіює універсальну ситуацію знищення гріха, унаслідок чого настає торжество благодаті» (Большев, 2017, с. 70).

Після мелодраматичного катарсису глядач/ читач має відчути певне емоційне полегшення, адже він вклав у це «ритуальне» дійство дещицю пожертви у вигляді співчуття «добру» та осуду «гріха». У «Тінях забутих предків» безсумнівним $\epsilon$ наявність емоційного регістру, який подібний до 
мелодраматичного. Але абсолютно відсутня інша ознака мелодрами -очікування дива. Дійсність у фільмі представлена не як утопічна казка, а у всій складності й неоднозначності людського буття.

Фільми, по які говоритиметься далі, так само як і зазначена стрічка, у фабулі чи в сюжеті містять любовну історію: «Вечір на Івана Купала», «Білий птах із чорною ознакою», «Вавилон XX». Вважається, що жанр характеризується передусім способом розгортання сюжету, який і формує емоційне ставлення глядача до художньої реальності твору. Мелодрама оперує традиційними композиційними «блоками»: початкове благополуччя, рокова подія i наступне поневіряння невинної жертви, які вирішуються прямо чи опосередковано - фінальною перемогою добра над злом.

Хоча жодна 3 аналізованих стрічок не може бути віднесена до мелодрами, усі етапи мелодраматичної оповідінаявні в сюжетах цих фільмів. 3окрема, сюжет фільму Ю. Іллєнка «Вечір на Івана Купала» за мотивами оповідання М. Гоголя побудований за канонами мелодрами: закоханий хлопець, Петро, скоює злочин заради одруження з дівчиною, потім божеволіє від усвідомлення, що скоїв гріх; $\epsilon$ сподівання героїні, Підорки, на те, що станеться диво - iї коханий, який згорів у хаті, оживе від щиросердної молитви жінки у церкві. Але кінонаратив тут опирається літературній основі, «сюжет перестає бути визначальним у сприйнятті фільму», режисер прагне передати «потік свідомості через колір і форму, майже без слів...» (Авраменко, 2010, c. 44). Часто доволі серйозні смисли у цій стрічці представлені абсурдно, як, приміром, купка попелу, що залишилася від Петра після пожежі. Жінки-плакальниці, замість своїх прямих функцій на похованні, пропонують Підорці оживити чоловіка (як вже було згадано) на прощі, у Лаврі. Постаті жінок, як і самої Підорки, у цій сцені мають таких кут нахилу до площини, на якій стоять, що ця подія здається нереальною, протиприродною, як і сам акт імовірного «воскресіння». У іншій, більш реалістичній інтерпретації, сцена була б сприйнята, як жанрова - мелодраматична, 3 наївністю чи марновірством спрямована на «диво». Натомість ми спостерігаємо доволі гротескні образи у нереальних обставинах. Смерть Петра є горем лише для його дружини, для глядача - це відплата за скоєний гріх - убивство невинної дитини заради збагачення. До слова, каяття Петра також представлене кумедно: чоловік намагається дістатися храму, який розташований на горі та постійно зривається додолу. Храмів, як виявилось, багато, але жоден недосяжний. Коли Петро бачить панотця, спочат- ку одного, потім їх стає дедалі більше й більше, і їхні постаті нереально маленькі. У цій абсурдності міцно переплелося комічне з трагічним.

Коли Петро ще не занапастив себе гріхом, то його життя було сповнене чуттєвості та краси. Буколічні пейзажі з квітучими деревами та буслами на дахах чепурних мазанок немов віщують довге та щасливе життя закоханим. Натомість герой отримує розпач до божевілля, а героїня - сокиру замість немовляти. Мелодраматизм тут явлений підспудно, на рівні етичних імперативів. Судячи зі сцені в лісі, з поцілунками та обіймами закоханих Підорки та Петра, до того моменту як герой поспілкувався з Басаврюком, - хлопець і дівчина $\epsilon$ лише глядачами у театрі абсурду, який розгортається навколо них. А після Купальської ночі вони вже стануть вертепними ляльками в руках невблаганної долі.

Без умовностей та гротеску представлене життя сільської української родини Дзвонарів у іншому фільмі Ю. Іллєнка «Білий птах з чорню ознакою» (1971). Проте метафори у кіновикладі цієї епічної історії не менш промовисті. Донька місцевого священника, красуня Дана, подобається старшим братам Дзвонарям. Один, Петро, симпатизує «совітам», інший, недовірливий та відлюдькуватий Орест, не може миритись із будь-якою владою над собою. Дана чекає рішучих кроків від когось iз братів, та, не дочекавшись, погоджується на шлюб із радянським солдатом, вочевидь із помсти братам. Мелодраматичний любовний трикутник, який розгортається за усіма канонами жанру тут знову ж таки є похідним від символічної подоби красивої жінки на саму Україну. Правда, яскравішим та переконливішим саме у цьому сенсі $€$ інший персонаж - принадна сільська повія Вівдя (Дж. Фірсова). Вона старша та вправніша за Дану, ii досвід спілкування з чоловіками сягає ще часів румунського панування у цій частині Буковини. Жінка безсоромно віддається чоловікам у військовій формі (маркер влади) і від таких гине (наказ на iii вбивство віддає німецький офіцер).

Побратись із Вівдею погодився лише односелець Георгій Дзвонар, але шлюб з українцем тривав лише до ранку. Жінка трагічно гине на порозі каплички, з нею немовби вмирає і розкішна краса іiі вбрання, барви іiї оселі, без неї світ цього села вже не міниться радістю буття, його тілесною принадністю.

Дана ж є образом нової/оновленої України але 3 не менш драматичною долею (повінчана з радянським солдатом, першу шлюбну ніч дівчина провела 3 «бандерівцем»). Вона ніяк не визначить- 
ся із уподобаннями, але, здається, що лише Ореста (Б. Ступка) вона любила щиро. Проте визнати його за чоловіка так і не наважилася. У цьому - внутрішній конфлікт Дани (Л. Кадочникова) Суперечності роздирають і самого Ореста, ватажка українських повстанців: він мусить бути вигнанцем на рідній землі, змушений бути суперником та супротивником рідного брата (І. Миколайчук). Любовні взаємини цієї стрічки є приводом для політичних трактувань, які докорінно змінювались із плином часу.

У світовому кінематографі є чимало фільмів, темою яких стала любов на тлі воєнних подій, образи та конфлікти яких так само можна інтерпретувати виходячи з політичних алюзій - це і доволі «жанрова» «Касабланка» (М. Кьортіс, 1942 р.) чи, приміром, більш складна для сприйняття стрічка «Нічний портьє» (Л. Кавані, 1974 р.). Можна докладніше зупинитись на стрічці «Останне метро» Ф. Трюффо (1980р.). Під час нацистської окупації Парижа театральна прима на ім'я Маріон (це жіночий образ - символ-уособлення країни ще з часів Французької революції) розривається між двома чоловіками - молодим актором, членом руху Опору та власним чоловіком, режисером єврейського походження, який переховується в підвалі театру. Також жінка не гидує залицяннями з боку представників окупаційної влади - але усе заради того, щоб не закрили театр. Критики закидали режисерові занадто промовисту метафоричність стрічки, глядача було позбавлено права на те, щоб побачити власне спонтанний перебіг подій.

У фільмі Ю. Іллєнка і близько немає такої однозначності у трактуванні образів та конфліктів. Як могли, творці ховали усе «крамольне» за «кон'юнктурними вимогами часу» (Мусієнко, 2009 , с. 360), адже «принцип класового підходу до мистецтва було витримано» (Мусієнко, 2009, c. 361). Беззаперечним є хіба факт культу краси, естетизації візуального українського обширу. За красивими обличчями героїв, за барвистими буковинськими квітками на килимах та сорочках, за мальовничими краєвидами режисер та оператор глибоко сховали ідею-мрію твору - рано чи пізно українські половинки «інь» та «янь» з'єднаються, усі іiі непримиримі суперечності нарешті зникнуть.

Колись, але не тоді, коли Дана та Орест танцювали свій останній танець, тоді вочевидь було ще зарано. До речі, цим чуттєвим дійством захоплювались як дослідники кіно, так і режисери. Зокрема М. Донской «весільний» танок побачив у двох часових вимірах, порівнюючи драматичне наповнення першого танцю (який відбувся весною і сповненій обопільної пристрасності та сподівань на щастя), з танцем осіннім, «в гіркому акомпанементі безнадійності» (Донськой, 2014, с. 122). Також режисер зауважив, що обидва танці - це не дивертисмент, а важливі події у фільмі.

Без єдиного слова, лише поглядами та дотиками у цих сценах актори передають спектр емоцій живих людей - не образів, не функцій. Людей, які стали жертвами обставин. Зовнішня достовірність подій та образів тут експонує мотиви, які притаманні фольклору чи легенді, а зрештою й самій мелодрамі. I Дана і Орест -грішні, кожен по-своєму, перед лицем сільської громади (вона тут постає в образі хору з давньогрецької трагедії). Але виправданням (вже перед глядачем) для них $є$ шлях до індивідуального, приватного щастя - що зрештою й є ідеологією мелодрами.

Також мелодраматичними за емоційним наповненням є епізоди з Катериною, матір'ю братів Дзвонарів. Надто вражає сцена, у якій Георгій, молодший син, хоче убити лелеку, який звив гніздо на даху Дзвонаревої хати. Мати (Н. Наум) не сварить хлопця, вона міцно обіймає сина-підлітка і немов заколисує, як малу дитину, оповідаючи легенду про цього птаха.

Скоріш несвідомо персонаж Дзвонарихи сприймається, як вкорінена в українську культурну ментальність (яка беззаперечно має відбиток християнства) аналогія з образом Богородиці. Мати у цій стрічці - це третій головний жіночий образ, який є уособленням споконвічної любові - безумовної любові до кожного з синів, символ жертовної відданості та терпіння. Постулати християнської етики, як сталі істини, які визначають моральні норми, формують уявлення про справедливість, добро і зло. Саме через це мелодрама й зберігає загальнолюдську значущість.

Мелодраматична мораль походить із теологічного, християнського контексту, з тієї його площини, що відповідає за безпосереднє, почуттєве сприйняття сакрального. Біблійні образи, аби справити особливе враження, можуть були використані мелодрамою як прямо, так і завуальовано. Більш відкрито апелює до свідомості глядача образом жінки з новонародженим немовлям на руках І. Миколайчук у фільмі «Вавилон XX». У фільмі сільські комунари представлені як перші християнинеофіти, проте саме образ Мальви є промовистою, але контраверсійною інтерпретацією канонічних сюжетів Святого Письма. Двоїстість цього жіночого персонажа цікава аналогіями як з Марією, матір'ю Христа, так і з Магдалиною, його ученицею. Логіка такої побудови образу мотивована розвитком сюжету - сільська гуляща, Мальва (Л. Поліщук), лише по-справжньому покохавши молодого 
поета Володю (А. Хостікоєв), зрікшись минулого, немов набуває нової іпостасі. Ї̈і колишні гріхи скасовуються прийняттям ідеології «рівності та братерства», а особливо вагітністю від комунара.

На рівні безпосередньої аналогії ці образи та сюжети не справляли б такого враження, якби, по-перше, були позбавлені індивідуальних рис, по-друге, у цій стрічці питома вага так званого емоційного забарвлення покладена на епізодидивертисменти, такі собі ліричні відступи. Вони безпосередньо не впливають на перебіг подій, не дають якоїсь особливої інформації про мотивування вчинків персонажів.

Найбільш емоційно вражаючі сцени дослідники поетичного кінематографа називають ліричними, надто коли мовиться про любовні стосунки. Ліризм, як ознака відтворення інтимної атмосфери з витонченим емоційним станом, може бути рисою, притаманною багатьом жанрам та стилям. Епізоди, на яких наголошується, розкривають стосунки між певними персонажами, але не через конкретні слова чи вчинки, а завдяки кінематографічним прийомам, що розкривають сутність того чи того героя оповіді. Так зустріч Фабіана (І. Миколайчук) з Мальвою (Л. Поліщук) немов відірвана від часу й простору. Майже суцільно вона відбувається під акомпанемент чутливої молдавської пісні. Ставлення красуні до схимника-філософа носить доволі амбівалентний характер: чи то вона намагається його звабити, чи зрозуміти через цього дивака сутність людського буття. Ймовірно також, що усе побачене відбувається в уяві Фабіана, який розривається між земним та горнім. А його жертовний фінальний вчинок - він отримує кулю, яка призначалась Мальві, засвідчує, що любов філософа до цієї жінки була такою сильною, що позбавила страху за власне життя.

Не можна оминути увагою і сцени Мальви й молодого поета Володі. Закохані спускаються в яр, де пасеться стадо корів. Тварини видають властиві їхньому спілкуванню звуки, які спершу зливаються в какофонію, потім набувають ритму. Згодом вони перетікають в низькі регістри чоловічого ансамблю, який тихо й повільно співає пісню «Йшли корови із діброви, а овечки з поля...». Закохані молоді люди віддаються коханню - чуттєвий, природний світ людських стосунків стає єдиним цілим із навколишнім буттям.

Доволі довга любовна сцена набуває свого значення зі зміною темпоритму: постріл «куркулів» у бік поета - і Мальва стрімголов мчить до коханого (з яким щойно попрощалась), ледве почувши постріл. Потім жінка, немов навіжена, розмовляє із мертвим коханим, зізнаючись, що вагітна. Тож ме- лодраматичний мотив утраченого кохання у цьому фільмі забарвлений ліризмом і метафоричністю.

До мелодраматичних елементів можна віднести й постать невідомої плакальниці, яка з'являється далеко в полі, біля самотнього дерева, якраз напередодні лиха. Біла постать - чи то мара, чи сільська божевільна - нарочито заламує руки. Її голосіння подібне чи то на голос птаха, який віщує недобре, чи то на заспів журливої пісні. Такі прийоми кінематографічної виразності не є прямою ілюстрацією до якоїсь конкретної сцени, вони не прив'язані до певної події, глядачеві надається свобода вільного трактування, можливість віднести цей образ до того чи іншого символу.

Мелодраматичні елементи, які застосовувались режисерами поетичного напряму, були до певної міри структуротворчими, адже впливали на сюжет у цілому чи підсилювали його окремі аспекти. Давати цим ознакам жанру мелодрами інші визначення на кшталт «ліричний» чи «романтичний» вважаємо недостатньо змістовним. Розподіл на «низькі» й «високі» жанри давно вже $\epsilon$ некоректним, як і розмови про те, що великі митці-кінематографісти творять поза жанром, тобто нехтуючи таким. Мелодрама має свій чіткий «робочий», суто утилітарний інструментарій, і режисер використовує його залежно від творчих завдань.

Естетичний взаємообмін між стилем поетичного кінематографа (індивідуальним у тому числі) та мелодрамою розширює також і діапазон виражальних засобів цього жанру. Мелодрама в мистецтві давно вже межує з такими гранями естетичної свідомості, як прекрасне, піднесене, трагічне, ліричне, і за необхідності переходить в них. Але залишає при цьому свої типологічні властивостіхарактерний загальний пафос із виокремленням основних домінант: співчуття, жалості та морального протесту проти несправедливості.

У згаданих стрічках, на нашу думку, мелодраматичний модус був переосмислений і застосований тою мірою, яка не давала змоги підкорити концепцію фільму, його світоглядні принципи ідеології «чистої» мелодрами. Принаймні митці переступили через дидактичне, моральне начало цього жанру, яке не допускає подвійних трактувань образів персонажів чи їхніх вчинків. Натомість було звернення до емоційного осердя цього жанру, на образи чи мотиви, які безпосередньо впливають на почуттєву сферу глядача.

Висновки. У статті розглянуто мелодраматичні елементи, які застосовувались режисерами поетичного напряму для створення особливої емоційності деяких сцен, встановлено структуротворчу 
функцію мелодраматичного модусу та його вплив на сюжет у цілому чи на емоційне підсилення його окремих аспектів. Виявлено естетичну взаємодію між фільмами поетичного кінематографа, зазначено, що текстова діалогічність зазначених стрічок спирається на спільні жанрові та культурні коди.

\section{Джерела та література}

Авраменко, А. (2010). Режисери проти літературоцентризму. Українське кіно від 1960-х до сьогодні. Проблема виживання: Зб. статей. Київ : Задруга. С. 41-51.

Аннінський , Л. (2014). Три ланки. Екранний світ Сергія Параджанова : Зб. статей / упор. Ю. Морозов. Київ : Дух і Літера. С. 54-63.

Большев, А. (2017). Мелодраматическая обида и трагическая вина. Мир русского слова. ‥ 4. С. 70.

Брюховецька, Л. (2014). «Тіні забутих предків» як художній маніфест. Екранний світ Сергія Параджанова : Зб. статей / упор. Ю. Морозов. Київ : Дух і Літера. С. 25-35.

Дзюба, I. (2014). День пошуку. Екранний світ Сергія Параджанова : Зб. статей / упор. Ю. Морозов. Київ : Дух Літера С. 15-24.

Донской, М. (2001). Поезія боротьби. Поетичне кіно: заборонена школа [Електронна копія] / зб. ст. та матеріалів / авт. ідеї та упоряд. Л. Брюховецька. Київ : Нац. ун-т «Києво-Могилянська академія», Каф. культурології та археології НаУКМА. АртЕк. Ред. журн. «Кіно-Театр». С. 121-126.

Кармилова, Е. (2008). Мифопоэтическая основа жанров современной массовой культуры (женский любовный роман/мелодрама) и рекламный дискурс. Вестник Санкт-Петербургского университета. Сер. 9, вып. 1. C. $120-129$.

Крутоус, В. (1981). О «мелодраматическом». Вопросы философии. Москва : Наука. № 5. С. 125-136.

Мусієнко, О. (2009). Українське кіно: тексти і контекст. Вінниця : Глобус-Прес. 432 с.

Скуратівський, В. (2014). Тіні забутих фільмів. Екранний світ Сергія Параджанова : Зб. статей / упор. Ю. Морозов. Київ : Дух і Літера. С. 36-47.

\section{References}

Avramenko, A. (2010). Rezhysery proty literaturocentryzmu [Directors against literary centrism]. Ukrayinske kino vid 1960-x do sogodni. Problema vyzhyvannya: Zb. statej. Kyiv : Zadruga. S. 41-51. [in Ukrainian]

Anenskyj, L. (2014). Try lanky [Three links]. Ekrannyj svit Sergiya Paradzhanova : Zb. statej / upor. Yu. Morozov. Kyyiv : Dux i Litera. S. 54-63. [in Ukrainian]

Bol'shev, A. (2017). Melodramaticheskaja obida i tragicheskaja vina [Melodramatic resentment and tragic guilt.]. Mir russkogo slova. N. 4. S. 70. [in Russian].

Bryuxoveczka, L. (2014). «Tini zabutyx predkiv» yak xudozhnij manifest [ «Shadows of Forgotten Ancestors» as an artistic manifesto.]. Ekrannyj svit Sergiya Paradzhanova : Zb. statej / upor. Yu. Morozov. Kyiv : Dux i Litera. S. 25-35. [in Ukrainian]

Dzyuba, I. (2014). Den' poshuku [Search day]. Ekrannyj svit Sergiya Paradzhanova : Zb. statej / upor. Yu. Morozov. Kyiv : Dux i Litera. S. 15-24. [in Ukrainian]

Donskoj, M. (2001). Poeziya borot'by'[Poetry of struggle.]. Poety 'chne kino: zaboronena shkola [Elektronna kopiya]/ zb. st. ta materialiv / avt. ideyi ta uporyad. L. Bryuxovecz'ka. Kyiv : Nacz. un-t «Kyevo-Mogylyan. akad.», Kaf. kulturologiyi ta arxeologiyi NaUKMA. ArtEk. Red. zhurn. «Kino-Teatr». S. 121-126. [in Ukrainian]

Karmilova, E. (2008). Mifopojeticheskaja osnova zhanov sovremennoj massovoj kul'tury (zhenskij ljubovnyj roman/ melodrama) i reklamnyj diskurs [The mythopoetic basis of the modern mass culture genres (female love story / melodrama) and advertising discourse]. Vestnik Sankt-Peterburgskogo universiteta. Ser. 9, vyp. 1. S. 120-129. [in Russian].

Krutous V. (1981). O «melodramaticheskom» [About «melodramatic»]. Voprosy filosofii. Moskva : Nauka. № 5. S. 125-136. [in Russian].

Musiyenko, O. (2009). Ukrayins 'ke kino: teksty' $i$ kontekst [Ukrainian cinema: texts and context.]. Vinny'cya : GlobusPres. 432 s. [in Ukrainian]

Skurativskyi V., V. (2014). Tini zabuty'x fil'miv [Shadows of forgotten movies]. Ekranny 'j svit Sergiya Paradzhanova: Zb. statej / upor. Yu. Morozov. Ky`yiv : Dux i Litera. S. 36-47. [in Ukrainian]

\section{Tetiana Zhuravliova}

\section{Melodramatic mode in Ukrainian poetic cinematography}

Abstract. The article exposes the influence of the melodrama genre on the structure of films of the Ukrainian poetic cinematography. The genre aspects in films of this field has not yet been thoroughly studied. The methodology of the research based on modus of the artistic text allows to reveal the semantic and plot elements existing within the work or system of works, which are built into the so-called modus constructions. On the basis of common aesthetic factors we can investigate the typology of the cinematic pieces of art from the point of the principles of the plot-image system.

Based on the intertextual principle of analysis of the screen work in the films revealed the affinity of semantics and plot elements. Emphasis is also placed on the existence of artistic dialogue between these films

Key words: poetic cinematography, melodrama, modus, intertextuality. The aesthetic interchange between poetic cinema and melodrama, which also expands the variety of means of expression of this genre. 